\title{
comunicação
}

\section{Marcelo Mancuso da Cunha (24/10/1962 - 29/05/2004): exemplo de dinamismo, talento e amizade.}

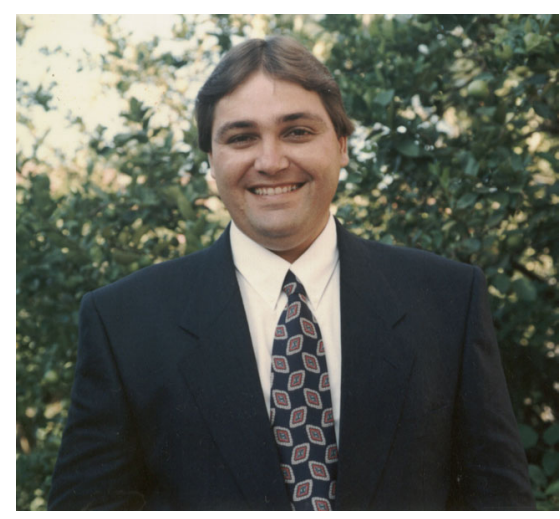

Marcelo Mancuso nasceu em São Paulo, SP, no dia 24 de outubro de 1962 , filho de Mário Chaves da Cunha e Apparecida Mancuso da Cunha, tendo como irmãos Alexandre Mancuso da Cunha e Luciano Mancuso da Cunha. Era casado com Maridel Piloto de Noronha, com quem teve três fillhas: Cecília (12), Ana Luisa (8) e Mariana (6).

Marcelo concluiu o primeiro grau em novembro de 1977, no Colégio Dom Bosco e o segundo grau em julho de 1980, no Colégio Objetivo, ambas instituições de ensino localizadas em Brasília, DF. Em março de 1981 ingressou na Universidade de Brasília (UnB), graduando-se em Engenharia Agronômica em julho de 1986. Em dezembro de 2002, obteve na UnB o título de Mestre em Fitotecnia tendo como título da dissertação: "Qualidade total em pequenas propriedades frutícolas de perímetros irrigados da Região Nordeste".

Iniciou suas atividades profissionais trabalhando na área de produção de sementes de hortaliças tendo estagiado, em várias ocasiões, no Centro Nacional de Pesquisa de Hortaliças - CNPH, hoje
Embrapa Hortaliças. De março de 1987 a julho de 1988 trabalhou na Empresa AJE - Assessoria Jurídica e Empresarial Ltda. De dezembro de 1987 a dezembro de 1989 foi gerente de produção da Ferraz Agropecuária Ltda.

Durante o período de junho de 1991 a julho de 1992, exerceu a função de especialista em Controle Fitossanitário junto ao Instituto Interamericano de Cooperação para Agricultura (IICA). Foi consultor do Programa de Apoio à Produção de Frutas, Hortaliças, Flores e Plantas Ornamentais - FRUPEX Ministério da Agricultura de outubro de 1992 a dezembro de 1995. Atuou como sócio gerente da empresa LUMMA Consultoria de Projetos LTDA entre 1994 e 1997. Desde agosto de 1997 atuava como consultor em pós-colheita e qualidade de frutas do programa de Cooperação Técnica - Secretaria de InfraEstrutura Hídrica/IICA, dando suporte técnico para implementação das ações de irrigação no Ministério da Integração Nacional.

Dentre as várias funções exercidas, pode-se destacar: membro do Grupo de Apoio Técnico e Especializado (GATE) do convênio CODEVASF/IICA, atuando no Projeto Senador Nilo Coelho; coordenador da Campanha de Controle da Traça do Tomateiro no Projeto Senador Nilo Coelho; responsável pela montagem do Centro de Diagnose e Triagem de Problemas Fitossanitários no Distrito de Irrigação do Projeto Nilo Coelho em Petrolina; Coordenador do Sub-programa de Fitossanidade do Programa de Apoio à Produção e Exportação de Frutas, Hortaliças, Flores e Planta Ornamentais - FRUPEX do Ministério da
Agricultura do Abastecimento e da Reforma Agrária - MAARA; Coordenador do Programa de Qualidade Total Rural - Fruticultura Irrigada - Convênio Ministério da Integração Nacional - MI/Serviço Brasileiro de Apoio às Micro e Pequenas Empresas SEBRAE; e membro da Comissão Editorial da revista Horticultura Brasileira desde novembro de 1997.

Durante sua vida profissional especializou-se na editoração de livros, cartilhas e boletins técnicos, relacionados com agricultura, que se destacavam pela simplicidade na apresentação do conteúdo e pela alta qualidade visual. Suas obras são sempre referências nas cadeias produtivas de frutas e hortaliças, principalmente, na fruticultura em áreas irrigadas.

Marcelo Mancuso foi também o responsável pela editoração da revista Horticultura Brasileira durante vários anos, primeiro como 'free lancer' e depois como membro da comissão editorial. O padrão gráfico da revista foi modernizado e constantemente atualizado graças a sua incansável busca pela qualidade e excelência profissionais, características marcantes de sua vibrante personalidade. A Sociedade de Olericultura do Brasil presta esta justa homenagem ao grande colega e amigo que durante 11 anos ajudou na elaboração da revista Horticultura Brasileira. Para todos nós, que tivemos o privilégio de trabalhar com Marcelo Mancuso, ficará o exemplo de dinamismo e competência, que resultou em grandes contribuições em todas as áreas nas quais atuou profissionalmente.

Editores da Horticultura Brasileira 